\title{
STUDENTS PERCEPTION ON ETHNIC RELATIONS COURSES: \\ A Case Study at Universiti Utara Malaysia
}

\author{
Muhamad Amar Mahmad \\ Pusat Pengajian Bahasa Tamadun dan Falsafah, \\ Universiti Utara Malaysia. \\ e-Mail:m.amar@uum.edu.my
}

\begin{abstract}
The Ethnic Relations Course introduced in 2006 at Higher Education Institutions (IPT) is an attempt to address the issues of ethnic relations that are often an issue in country development. The course is a national medium towards creating an ethnical integration with diverse backgrounds of belief and culture. However, ethnic differences will certainly create diverse perceptions among students. If this is the case, then the offer of the course will not achieve its goal. The main objective of this study is to examine the students' attitudes based on the ethnic factors influencing the course offering. The research instrument was developed by the researcher based on the objectives of the course. Respondents were randomly selected from 300 people comprising of second semester Ethnic Relations course students in 2016/2017 at UUM. The findings showed that ethnic factors also influenced the perceptions difference between students towards the offer of Ethnic Relations course although not significant. To overcome this distinction, the government should extend the basic concepts of the course to students since the schooling.
\end{abstract}

\section{INTRODUCTION}

Malaysia is synonymous with plural society because its people are of various races, languages, identities, religions and so on. The plural society in the Malaysian context has been 
widely studied by scholars and has been documented (Purcell, 1967; Freeman, 1960). This plural term was introduced initially by J.S. Furnival (1948) in his study of people in Burma and Indonesia which refers to the characteristics of disunity and conflict between ethnic groups under a system of government or politics. The diversity of people will certainly create multi-cultural, multi-religious and multilingual. This distinction must be understood and appreciated by every one of the Malaysians. Violation of sensitive issues due to not being concerned about a race may invite disasters as happened in the event of May 13, 1969.

Hence, the government's initiative has introduced the Ethnic Relations course under the Ministry of Education to be the core subject to the entire Public Institution of Higher Learning. This course is expected to provide students with an understanding of ethnocentrism, stereotypes and prejudices among them, although they are of different races, religions, languages and so on. Not only that, when they hold graduates someday they will act as government agents in helping to achieve the government agenda through the idea of 1 Malaysia as a formula for achieving Vision 2020.

Therefore, this study will attempt to identify students' perceptions on the Ethnic Relations course from ethnic factors in Universiti Utara Malaysia Sintok kedah. 


\section{RESEARCH OBJECTIVE}

The purpose of this research is to study the influence of ethnic factors on the Ethnic Relations course among students of Universiti Utara Malaysia Sintok kedah. The ethnic factors that are meant are ethnic Malays, Chinese, Indians and others of Siam, Sikh and so on will certainly give different perspectives.

\section{Introduction}

The birth of racial diversity in Malaysia to date has been the result of the British colonial intervention in socio-political structure by introducing the entry policy of Chinese and Indian migrants without restrictions. However, according to Shamsul Amri Baharuddin (2012), the beginning of the plural society has indirectly been in existence since the time of the Malay Sultanate of Melaka again with their arrival without being forced. As a result, merchants from Arab, Indian and Chinese and other countries are free to trade and interact with the Malayan population that formed the Baba and Nyonya communities, the Malays of the Indians and Malays of Indians.

In fact, from the beginning of the second decade of the 20th century, the Malay Peninsula changed its community landscape consisting of quite complex plural society (Tregonning, 1967). String of that, then the population of society continues to breed eventually becoming a society that breeds diverse human beings from cultural, religious, social and so on. Consequently, issues involving sensitivity should 
be properly addressed by ethnics inhabiting Malaysia to maintain harmony regardless of the context of the upper, lower or subordinate class.

Meanwhile, the government's efforts towards making education as a means of integration have been highlighted by introducing the Ethnic Relations course across IPTAs in Malaysia, especially among university students. The government's move is to inculcate amongst students so that the concept of cultural relativity is fully understood and appreciated and not only as a requirement of university courses. The cultural evaluation of a nation must be measured through its own culture (Herskovits, 1948). If this relative nature is absorbed as a principle in an individual's life, the ethnocentrism of nature will no longer be within themselves. This is because these are the ones that will drive the country's administration in the future, whether the direction brought is contradictory or otherwise. In Islam, however, this aspect of plurality is highly regarded without neglecting certain ethnicities in terms of denial of rights amongst them (Department of Islamic Development Malaysia, 2005).

In the same development, according to minister in the Prime Minister's Department, Tan Sri Joseph Kurup in a press conference after officiating the 3rd Conference on Citizenship Strengthening states that the module of Ethnic Relations adopted in all universities in Malaysia should also be introduced at primary level. This is because not all students will track their legs to the ivory tower and if not initiated at this stage any drop-out students will certainly miss out on the 
exposure. This call was made after seeing lately, sensitive issues began to be triggered by irresponsible people such as the issue of the use of the Word of God by Christians to be adopted in their religion (Sinar Harian, 19 January 2014). While the word is a sacred word for Islam and Muslims and it can not be used or equated with other non-Muslim religions (http://www.e-fatwa.gov.my). In addition, the issue of pig heads placed at Nurul Iman mosque door in Rawang Selangor on February 2, 2012 also triggered a phenomenon that should not have happened. This is a form of provocation towards racial and religious sentiments (Sinar Harian, January 19, 2014).

Hence, with the government's move through the Ministry of Education, introducing the Ethnic Relations Courses as a core course and must pass as a condition for graduates is an exact step. While the government is working hard to make the subject a national medium, the extent to which the course is able to attract students in fulfilling the country's dream needs to be addressed. This factor determines the effectiveness of courses offered whether they achieve objectives or otherwise.

The emergence of differences in the perceptions of different ethnic groups will certainly exist. Additionally, university students have different backgrounds of schooling. The government hopes that the course will be a racial integration platform amongst university students will fail if the course is viewed disadvantaged by different ethnicities and different school trends. Perhaps for their Malay ethnic 
students they are delighted with this course as its content touches on the privileges and rights of the Malays, the Malay language, the Islamic religion and the position of Malay rulers in the context of Malaysia's constitution. On the other hand, other ethnic students view this course bias because there seems to be no equality given while they are Malaysians too.

The question of these issues will determine the context of future ethnic relations and depends on how the question can be solved (Ratnam, 1969). The findings of the study have been conducted by Hamidah Abd Rahman, et al. (2011) on Universiti Teknologi Malaysia (UTM) students found that the level of rapport between ethnic is very modest in all fields except in discussions related to learning. As a result, introducing the Ethnic Relations course to all multicultural students is expected to be able to understand and adhere to what has been enshrined in the Malaysian constitution. This is because it is based on social agreements that have been mutually agreed before demanding independence. According to Salleh Buang (2007), in recent times there have been parties who are trying to insist that the social contract be eliminated or reviewed. Among the seedlings in the direction are the claims by the Federation of Malaysian Chinese School Board Managers (Dong Zon) on the implementation of the Malaysian Education Development Plan (PPPM). The claim is that the government should abolish the conditions imposed for the construction of schools, demanding that the government incur the cost of construction and land for Chinese schools and implement various education policies 
against a system practiced today. What is demanded by these Chinese societies proves that they really want to exclude the Chinese from the social flows and the development of this country. This claim according to Tan Sri Muhyiddin Yassin in opposition to national policy because (PPPM) is based on the Constitution of the country. According to Dong Zone, the plan is also an act of repealing national schools (SJK) (Berita Harian, August 23, 2013).

Therefore, if these aspects are a barrier to the effectiveness of students in achieving the objectives of the course, then the government's desire is to go through the Higher Education Ministry to instill in character among students regardless of ethnicity. As such, these issues should be seriously addressed and seriously concerned by all parties involved in the search for their completion point so that the course can really set aside the terms of the Chinese, Malay, Indian and others but all of them are Malaysians in line with the idea a Malaysia introduced by the Prime Minister on April 2, 2009.

\section{Theoretical Review}

The population of this study involved students taking the Second Semester Ethnic Relations subject in 2016/2017 at UUM. In this study, a total of 295 randomly selected students and respondents will be classified into four main groups namely Malay, Chinese, Indian and others. To obtain some data sourced from the library, the library research method was used. In addition, survey methods were 
conducted using questionnaires. This method is performed to get the responses from the respondents. Instruments in the questionnaire were constructed by the researchers themselves and reviewed by experts for verification and then piloted studies to determine the reliability of the instrument.

Measurement of this idea is made using the five point Likert scale: 1: Strongly Disagree, 2: Disagree, 3: Undecided, 4: Agree and 5: Strongly Agree. There are a total of 21 items of questions with its circular system having composite data to illustrate the perceptions of students towards the Ethnic Relations course from low to high. Questions 10 and 20 are negative questions while the remaining questions are positive. For the reverseed decoding of negativistic questions will be made to be consistent with the positive questions. The data obtained were analyzed using the Statistical Packages for Social Science (SPSS) version 19. The method used was the descriptive statistical method used in the form of frequency, percentage, mean and standard deviation.

The majority of the respondents involved in this study were $223(75.6 \%)$ female students compared with 72 male students $(24.4 \%)$. Of the total, more than half of the respondents were enrolled in National Secondary School which was 166 people (56.3\%). Then followed by Diploma Program / Matriculation / Foundation for 97 people (32.9\%), Religious High School of 18 (6.1\%) and National Type Secondary School (SMJK) at least 14 (4.7\%). In view of the background of life, there is no significant difference between 
respondents in which 163 people (55.3\%) come from rural communities while 132 people (44.7\%) come from urban communities. In the context of racial fragmentation, the majority of these respondents were Malays, ie 198 (67.1\%), followed by 79 Chinese (26.8\%), India 9 (3.1\%) and other ethnic groups including Siam and various ethnic groups in Sabah and Sarawak also 9 persons (3.1\%). Table 4.1 below shows the distribution of respiratory personal descriptive information involved in this study.

Table 4.1: Respondent's Personal Descriptive Information

\begin{tabular}{|l|r|r|}
\hline \multicolumn{1}{|c|}{ Category } & $\begin{array}{c}\text { Frequency } \\
(\mathbf{n}=\mathbf{2 9 5})\end{array}$ & \multicolumn{1}{c|}{ Percentage } \\
\hline Sex & & 24.4 \\
\hline Male & $\mathbf{7 2}$ & $\mathbf{7 5 . 6}$ \\
\hline Female & $\mathbf{2 9 5}$ & $\mathbf{1 0 0}$ \\
\hline Total & & \\
\hline & & 56.3 \\
\hline Level of education & 166 & 4.7 \\
\hline SM National & 14 & 6.1 \\
\hline SM (J) National & 18 & 32.9 \\
\hline SMK Agama & 97 & $\mathbf{1 0 0}$ \\
\hline Diploma /Matriculation / & $\mathbf{2 9 5}$ & \\
\hline Total & & \\
\hline & & 44.3 \\
\hline Original Residence & 163 & \\
\hline Rural & 132 & \\
\hline City & & \\
\hline
\end{tabular}




\begin{tabular}{|l|r|r|}
\hline Total & $\mathbf{2 9 5}$ & $\mathbf{1 0 0}$ \\
\hline & & \\
\hline Races & & \\
\hline Malay & 198 & 67.1 \\
\hline Chinese & 79 & 26.8 \\
\hline India & 9 & 3.1 \\
\hline Others & 9 & 3.1 \\
\hline Total & $\mathbf{2 9 5}$ & $\mathbf{1 0 0}$ \\
\hline
\end{tabular}

This study has divided into several ethnic groups, namely ethnic Malay, Chinese, Indian and others. Other ethnicities involve such as the Originals, Siamese, Sikhs in Malaysia and the ethnicities in Sabah and Sarawak. The findings show that there is no significant relationship between the perceptions of the ethnic relations course and the influence of ethnic factors among the students $(\mathrm{f}=.00$ ). Of all the respondents, the ethnic Malays recorded the highest mean score $(\mathrm{min}=87.70)$, followed by the second Indian $(\min =87.33)$, and others $(\min =84.00)$. Ethnic Chinese recorded the lowest scores of the perceptions of the importance of the Ethnic Relations course offered ( $\mathrm{min}=$ 80.37). Table 4.6 below shows the mean score of perceptual differences based on the influence of the ethnic factors of the students on the Ethnic Relations course. 
Table 4.6: Perceptions of student perceptions based on ethnic factors

\begin{tabular}{|l|r|r|r|}
\hline \multicolumn{1}{|c|}{ Ethnic } & \multicolumn{1}{c|}{ Standard } & \multicolumn{1}{c|}{ Deviation } & \multicolumn{1}{c|}{ F } \\
\hline Malay & 87.70 & 9.59 & .00 \\
\hline India & 87.33 & 7.69 & \\
\hline Others & 84.00 & 12.53 & \\
\hline Chinese & 80.37 & 9.68 & \\
\hline
\end{tabular}

\section{DISCUSSION}

The findings show that the mean Malay and Indian students in the Ethnic Relations course are extremely high. For Malay students, the researchers see that they are responding positively is because this course contains content that discusses the privilege of the Malays in the context of the Malaysian Constitution. According to Salleh Abas (1985), the privileges include civil service, granting scholarships and assistance, or other educational facilities and permits and the necessary deductions for business and trade. In addition, this course directly addresses Islam in one chapter ie Islam and ethnic relations in the seventh chapter and indirectly touching other chapters. This climate is also in line with the results of the study conducted by Nazri Muslim et al. (2011) on the level of student acceptance of the Malaysian constitution in selected IPTAs namely UM, UKM, USM and UPM. The results showed that the acceptance rate for Malay students was the highest (67.4\%), followed by India (54.1\%) and the lowest being Chinese (38.4\%). Hence, in order to maintain the 
harmony of ethnic relations other than the Malays, then issues relating to the privilege of the Malays should use a pragmatic approach. This approach is similar to Faridah Jalil (2007) which reminds us that the issue of Islam and the Malays in the constitution is constantly tidal if the level of acceptance of non-Malay students is not properly addressed. This is because the students will be leaders and of course their views will affect the thinking of a society.

In the context of Chinese students, it seems as though they are looking at this ethnic relations course in favor of one race only - Malays while they are not treated equally as Malaysians. In addition, the nature of ethnocentrism inherent in them by feeling their own nation or culture and underestimating other nations and cultures (Ismail Yusoff, et al.). In view of the historical perspective of their cultural development, Kennedy (1994) states that Chinese civilization has been recognized as the greatest civilization in the history of human civilization, especially during the dynasty of the Ming Dynasty. The pride of the Chinese against his civilization was very thick from generation to generation despite the changing times. These groups had once opposed the basics that were said to be detrimental to their cultural identities such as Chinese language and school issues (Haris Md., 1990). According to Purcel (1975) they also have a strong influence in their religion since the beginning of Buddhism and Taoism. In addition, another religion which is said to be very influential to the Chinese community is the teachings of 
Konfucius (Jeffrey Seow, 1999). Historians however, however, state that Konfucus's teachings are not a religion because of more political and educational thinking. However, Smith (1998) stated that the teachings of Confucius were religiously based on the reason that a way of life was considered religious. If viewed from the content of the ethnic relations course there is significant significance with the Chinese perceptions of this course based on the strong historical relevance of religion. Not only that, but they also regard Islam and the Malays as the same thing that people convert to Islam are said to have turned their faces to Malay. This assumption is based on statements by Lee Kam Hing and Tan Chee-Beng (2000) stating that:

"The general rejection of Islam by Chinese Malaysians is not so much a rejection

of the religion but disapproval of discarding Chinese identity "

In addition, ethnic Chinese since their independence they are cynical about Islam although in federal constitution it is official religion. According to (Mahayuddin, 2001; Nuraisyah, 2006) this negative perception, as they consider that Islam is a religion of retreat, extreme and supportive. It is noteworthy that not only among Malay researchers, but also by the Chinese and Chinese Chinese researchers themselves (Mazuen, 2005; Ann Wang Seng, 2009; Lee \& Tan, 2000). These poor perceptions should not exist because of the 
various efforts undertaken by the government towards increasing understanding of Islam, especially among nonMuslims. The proof of the practice of pure values in the work during the Tun Mahathir era was then resumed by Tun Abdullah Ahmad Badawi with some improvements and made a new emblem known as Islam Hadhari (Ahmad Atory Hussain, 2006). In addition, according to Mohd Yusof (2003) other approaches such as introducing moral subjects, Tasawwur and Islamic Education in schools.

While Indian students have shown a positive response to the Ethnic Relations course compared with Chinese students is due to their culture being similar to the Malays. According to (Asmah Omar, 1975; Noresah Baharom, 2006) assimilation of new concepts and ideas can be seen through lending and absorption elements from Indian culture and language, especially Sanskrit and some Tamil language into Malay culture and language. Examples of absorption from the Sanskrit language such as the original earth of bhumi, the devotion of the origin of devotion and the origin of Bhudi. Whereas from the Tamil language such as the original jug of kendii, the origin of petti and the origin of kappal. According to Hashim Musa (2000), explaining the close relationship between India and the Malay nation has taken place in a long period of history. This can be seen through old Malay literature such as Hikayat Merong Mahawangsa, Lima Pendik Hikayat, Hikayat Maharaja Pikrama Sakti and others. Furthermore, through a study conducted by Mansor Mohd. Noor, et al. (2001) found that Indian students had no problem 
in establishing ethnic cross-ethnic relations with other ethnic groups who were willing to share rooms with other ethnic colleagues at the institute of higher learning.

Therefore, although Malaysia is said to be a peaceful and harmonious state in the context of ethnic diversity, compared to other countries, according to some scholars such as Shamsul Amri (2005), Malaysia's inter-ethnic relations are tense but stable while Khoo Kay Kim 2007) is of the opinion that Malaysia is in a state of 'worrying and fragile state'.

\section{CLOSING}

The Ethnic Relations Course is a very important course especially in the Malaysian climate comprising ethnic diversity. Based on the findings, it is clear that students' perceptions of this course are very good, but there are things that need to be addressed so that the government's pure desire to make this course a catalyst for ethnic integration among students can be realized. If it is observed that the whole of the Ethnic Relations course is highly relevant as it does not only touch cultural and social matters, it is merely discussing the rights of racial diversity in accordance with the Malaysian constitution as long as it has been agreed upon in a social contract. 


\section{REFERENCES}

Ahmad Atory Hussain. Islam Hadhari: Suatu Kesinambungan

Dasar Penerapan Nilai-Nilai

Islam selepas Era Tun Dr. Mahathir Mohamad. Journal of Ethics legal and Governance. Vol 2. (1-10), 2006.

Ann Wan Seng. 2009. Murtad: Jangan Pandang Sebelah Mata. Kuala Lumpur: MustRead.

Asmah Hj. Omar.1975. Essays on Malaysian linguistics. Kuala Lumpur:Dewan Bahasa dan Pustaka.

Berita Harian, 23 Ogos 2013.

Faridah Jalil. 2007. Perlembagaan Persekutuan menangani cabaran semasa dan mendatang.

Dlm. Faridah Jalil (Peny.). Undang-undang Malaysia: 50 tahun merentasi zaman.

Bangi: Fakulti Undang-Undang UKM.

Freeman, MB. 2006. Society. Australia: University of Wollongong.

Furnivall, J.S. (1948). Colonial Policy and Practise.

Cambridge: Cambridge University Press.

Hamidah Ab Rahman, et al. Kajian Tinjauan Hubungan Etnik

Dalam Kalangan Pelajar

Tahun Satu di Kampus Johor Bahru, UTM. Jurnal Teknologi. ( 54 ), 65-75, 2011.

Hashim Hj. Musa. 2000. Pemerkasaan Tamadun Melayu Malaysia Menghadapi Globalisasi

Barat. Petaling Jaya: DJ Gemilang Sdn Bhd.

Herskovits, M.J. (1948). Man and his Works: The Sciences of Cultural Anthrophology. New 
York: Knopf.

Ismail Yusof et. al. 2012. Hubungan Etnik. Selangor: Pearson Malaysia Sdn Bhd.

Jabatan Kemajuan Islam Malaysia. (2005). Islam Hadhari: Satu penjelasan. Kuala

Lumpur: Jabatan Kemajuan Malaysia.

Haris Md Jadi. 1990. Etnik, Politik dan Pendidikan. Kuala Lumpur: Dewan Bahasa dan Pustaka.

Jeffrey Seow (Illustrator). 1999. The Complete Analects of Confucius. Jil.3. Singapore:

Asiapac Books Pte Ltd

Kennedy, P. 1994. Kebangkitan dan Kejatuban Kuasa-Kuasa Besar.

Terj. Kuala Lumpur:

Dewan Bahasa dan Pustaka.

Khoo, Kay Kim. 2007. The Making of Malaya, 1946-1955:

The Fruits of Ethnic Cooperation.

Dalam Voon Phing Keong (Ed.). Malaysian Chinese and Nation

Building: Before Merdeka and Fifty Years After. Kuala Lumpur: Centre for Malaysian Chinese Studies

Lee Kam Hing \& Tan Chee-Beng. 2000. The Chinese in Malaysia. Selangor: Oxford University

Press.

Lee, Kam Hing \& Tan, Chee Beng (Eds.). 2000. The Chinese in Malaysia. New York: Oxford

University Press.

Majlis Fatwa Kebangsaan. http://www.e-fatwa.gov.my

Mahayuddin Yahya. 2001. Islam di Alam Melayu. Kuala Lumpur: Dewan Bahasa dan Pustaka. 
Mansor Mohd Noor. 2005. Integrasi Etnik di IPTA. Pulau Pinang: Institut Penyelidikan

Pendidikan Tinggi Negara.

Mazuen Yahaya. 2005. Islam Pilihanku: Pengucapan Syahadah 39

Insan di Malaysia. Kuala

Lumpur: Karya Bestari Sdn. Bhd.

Mohd Salleh Abas. 1985. Unsur-Unsur Tradisi dalam Perlembagaan Malaysia. Kuala Lumpur:

Dewan Bahasa dan Pustakan.

Mohd Yusuf Ahmad. 2003. Pengajian Islam. Kuala Lumpur: Penerbit Universiti Malaya.

Nazri Muslim, Nik Yusri Musa dan Ahmad Hidayat Buang. Hubungan Etnik di Malaysia

Dari Perspektif Islam dalam Jurnal Kajian Malaysia. Vol. 29, 2011.

Noresah Baharom. 2006. Jubli Emas Dewan Bahasa dan Pustaka. Kuala Lumpur: Dewan Bahasa dan Pustaka

Nuraisyah Chua Abdullah. 2006. Kisah Saya: Saudara baru. PTS Publications \& Distributors.

Sdn. Bhd.

Purcell, Victor. 1965. Malaysia. London : Thames \& Hodson Ltd.

Purcell, Victor. 1975. The Chinese in Malaya. Kuala Lumpur: Oxford University Press.

Ratnam, K. J. 1969. Communalism and the political process in Malaya. Kuala Lumpur:

University of Malaya Press. 
Shamsul Amri Baharuddin. 2005. Islam Embedded: Religion and Plurality in Southeast Asia as a

Mirror for Europe. Asia Europe Journal. 5(8): 159-178.

Shamsul Amri Baharuddin. 2012. Modul Hubungan Etnik. Institut Kajian Etnik: Universiti

Kebangsaan Malaysia

Sinar Harian, 19 Januari 2014.

Smith, Jonathan Z. 1998. Religion, Religions, Religious, in Critical Terms for Religious Studies.

edited by M.C. Taylor, University of Chicago Press, Chicago, pp. $275-280$.

Tregonning, K.G. 1967. A History of Modern Sabah North Borneo 1881-1963). Kuala Lumpur: University Of Malaya Press. 